\title{
Effect of calcium Nitrate and Gibberellic Acid Foliar Sprays on Fruiting and Fruit Quality of "Manzanillo" and "Dolce" Olive Cvs.
}

\section{E. G. Mikhail and K. G. Goargios}

Olive and Fruits of Semi Arid Zone Department, Horticulture Research Institute, Agricultural Research Centre, Cairo, Egypt.

\begin{abstract}
7 HIS WORK was implemented to study the impact of foliar applications of calcium nitrate at $3 \%$ provided with (Gibberellic acid) at $10 \mathrm{ppm}$ and $20 \mathrm{ppm}$ at full bloom (mid-April), at fruit set stage (mid-May) and at pit hardening stage on 'Manzanillo' and 'Dolce' olive cvs during 2012 and 2013 seasons. This experiment was carried out at an olive private farm ( 9 years old) at Cairo Alexandria desert road (90 kilometer). The olive trees were planted at 4 × $6 \mathrm{~m}$ and irrigated using drip irrigation system. In olives, yield together with fruit quality determinations crop value and farmer profits. Yield depends on the number of fruits cropped per tree and their average weight fruit and flesh weight and oil content are the most important determents of on-tree fruit quality. Calcium play significant roles in fruit set, fruit growth and maturation. Calcium nitrate at $3 \%$ plus $\mathrm{GA}_{3}$ at 10 and $20 \mathrm{ppm}$ were applied as foliar sprays in three stages, mid April, mid May and during pit hardening. All, treatments have significantly reduced percentage of fruit drop and increased yield ( $\mathrm{kg} /$ tree). Fruit yield had pronounced increases over the control with mid May treatment to score 47.5 and $57.6 \%$ in the first season, 54.5 and $70.9 \%$ in the second one, respectively. Best results were brought about when calcium nitrate at $3 \%$ plus $\mathrm{GA}_{3}$ at 10 and $20 \mathrm{ppm}$ were applied in mid May followed by treatments during pit hardening and mid April, respectively. Such treatments have also had significant impacts on fruit, seed and flesh weight.
\end{abstract}

Keywords: Manzanillo cv., Dolce cv., Calcium nitrate, Gibberellic acid, HoklyGib, Fruit set, Fruit drop, Moisture content, Oil content.

The Olive is one of the most widely cultivated and economically important fruit crop for several subtropical Mediterranean countries olive trees are adaptable to a wide range of soil types. In Egypt, olive trees play an important economical role in the newly reclaimed area because of its ability to withstand the stress conditions. Olive is one of the fruit crops that can grow in sandy soil due to its capability to tolerate drought conditions. Manzanillo cv. Trees under the environment of Egypt, is subjected to high fruit drop after fruit set (Beltran et al., 2004). During fruit development, spraying with calcium nitrate may improve the middle lamella of the cell and alleviate the dropping of its fruits, concerning the Dolce cv., it bears heavy load of fruits but the size of fruit may be small and have inferior size in marketing, therefore the application of $\left(\mathrm{GA}_{3}\right.$ at $\left.10 \& 20\right) \mathrm{ppm}$ at full bloom stage, at fruit set stage and pit hardening may improve the fruit size (Casero et al. (2002) and El-Sese (2005). 
Calcium provides cell wall rigidity by cross-linking of pectic chains of the middle lamella (Glenn et al. 1988 and Tretyn, 1994). Disintegration of cell walls and the collapse of affected tissues are typical symptoms of calcium deficiency (Marschner, 1995). Proportion of calcium pectate in cell walls is very important for the ripening of the fruit. The increase of fruit calcium content leads to increase fruit firmness and delays fruit ripening or prevents calcium-related disorders (Ferguson \& Drobak, 1988 and Zocchi \& Mignani,1995). A fruit is an organ with a low rate of transpiration and in spite of high concentration of calcium in soil solution just a little of this element can be needed (Himelrick and McDuffie, 1983). High growth rates of low-transpiring organs increase the risk of calcium tissue content falling below the critical level required for cell wall stabilization and membrane integrity. Foliar calcium spraying can be an effective way of increasing its concentration in fruits (Casero et al. 2002, Neilsen \& Neilsen, 2002 and Tomala \& Soska 2004). The effect of this treatment depends however on environmental factors connected with the technique of spraying, salt concentrations, time and number of treatments and type of fertilizers used (Mengel, 2002). Tomala (1997) recommends the first spray of winter apple cultivars with calcium salts at the beginning of June, not later than in the second half of June. According to a great number of studies, foliar application of calcium on apple trees was effective in the second half of vegetation period, when the delivery of Ca ions to fruits uptake by roots rapidly decreased (Zavalloni et al. 2001, Casero et al. 2002 and Neilsen \& Neilsen, 2002). Calcium transported by xylem is moved effectively to young fruits, as organs of high metabolism rate and transpiration at the early stage of development. In the later period of fruit growth and ripening the transport of calcium can be limited to phloem, so spraying olive trees with calcium nutrients can improve fruit set, oil production and quality in Manzanillo olive (Desouky et al., 2009).

Gibberellins are known for their ability to increase cell enlargement (Arteca, 1996, Davis, 2004 and Pharis \& King, 1995), thus enhancing fruit growth in certain species such as citrus (Eman et al., 2007 and El-Sese, 2005), litchi (Stern \& Gazit, 2000 and Chang \& Lin, 2006), guava (El-Sharkawy et al., 2005), pear (Zhang et al., 2007) olive (El-khawaga et al., 2007), and (Makwana et al., 2010) on Jatropha.

The aim of the present investigation was to evaluate the effect of foliar spray of Calcium nitrate (at 3\%) and $\mathrm{GA}_{3} 10$ and $20 \mathrm{ppm}$ in April \& May and during pit hardening on fruit drop, yield and fruit quality of Manzanillo and Dolce olive cultivars.

\section{Materials and Methods}

The present study was carried out during 2012 and 2013 growing seasons on nine- years -old "Manzanillo and Dolce" olive trees, planted in a private farm at Cairo Alexandria desert road. Trees were uniform in shape and size as possible and planted at $6 \times 4$ meters apart in sandy loam soil and irrigated with drip irrigation from well (underground water). Trees received normal Horticultural Practices and Pest Control Program according to (El-Sayed and Abou Shanab, 2011).

Egypt. J. Hort. Vol. 41, No.2 (2014) 
This research was carried out to study the effect of calcium nitrate and (Gibberellic acid) HoklyGib at $\left(10 \& 20\right.$ ppm $\left.\mathrm{GA}_{3}\right)$ as foliar applications on "Manzanillo and Dolce" olive cvs. A randomized complete block design with three replicates per treatment (one tree per replicate) were adopted in this study. Foliar sprays were started in April, May and during pit hardening according to the following treatments:

- Control.

- Spraying calcium nitrate at $3 \%$ and HokleyGib $\left(\mathrm{GA}_{3}\right)$ at $10 \mathrm{ppm}$ concentration at full bloom stage in mid April.

- Spraying calcium nitrate at 3\% and HokleyGib $\left(\mathrm{GA}_{3}\right)$ at $20 \mathrm{ppm}$ at full bloom stage in mid April.

- Spraying calcium nitrate at 3\% and HokleyGib $\left(\mathrm{GA}_{3}\right)$ at $10 \mathrm{ppm}$ at fruit set stage in mid May.

- Spraying calcium nitrate at 3\% and HokleyGib $\left(\mathrm{GA}_{3}\right)$ at $20 \mathrm{ppm}$. at fruit set stage in mid May

- Spraying calcium nitrate at $3 \%$ and HokleyGib $\left(\mathrm{GA}_{3}\right)$ at10 ppm during pit hardening.

\section{Measurements}

Fruiting

Number of fruit set at the beginning of May, and number of fruits in mid June and before harvesting at the beginning of September were calculated per meter.

Fruit quality: Thirty fruit per each tree were randomly picked for carrying out the fruit quality measurements:

Fruit length $(\mathrm{cm})$, fruit diameter $(\mathrm{cm})$, fruit shape index, fruit weight $(\mathrm{g})$, flesh weight $(\mathrm{g})$, seed length $(\mathrm{cm})$, seed diameter $(\mathrm{cm})$, seed weight $(\mathrm{g})$.

Yield: average yield per tree was calculated for each treatment $(\mathrm{Kg} / \mathrm{tree})$

Oil percentage as dry weight. was determined by means of Soxhlet extraction apparatus using petroleum ether at $60-80^{\circ} \mathrm{C}$ boiling point as described by A.O.A.C. (1975).

\section{Statistical analysis}

The experiment layout included in this study followed a randomized complete block design in a factorial experiment. The obtained data during the two experimental seasons were subjected to analysis of variance (ANOVA) according to Snedecor and Cochran (1980). Differences between treatments were compared by using multiple range test (Duncan, 1955) as described in the SAS (SAS, 1986).

\section{Fruiting and yield}

\section{Results and Discussion}

Data presented in Tables 1 and 2 show the effect of foliar sprays of calcium nitrate at $3 \%$ and $\left(\mathrm{GA}_{3}\right)$ at $(10 \& 20 \mathrm{ppm})$ in mid April, mid May and at pit hardening on fruit set $/ \mathrm{m}$, fruit retained $/ \mathrm{m}$, No. of fruit drop/m, percentage of fruit

Egypt. J. Hort. Vol. 41, No.2 (2014) 
drop and yield (Kg/tree) of 'Manzanillo' and 'Dolce' olive cvs. during 2012 and 2013 seasons. It is clear that Dolce olive trees surpassed Manzanillo in fruit $\mathrm{set} / \mathrm{m}$, retained fruit $/ \mathrm{m}$ and yield in both seasons. On the other hand, Manzanillo cv. attained the highest fruit drop percentage in all treatments of Dolce and Manzanillo cvs.

Moreover, foliar tested application of calcium nitrate at $3 \%$ and (Gibberellic acid) HoklyGib (10 \& 20 ppm) in mid May and pit hardening on Dolce and Manzanillo gave the highest significant values of fruit set $/ \mathrm{m}$, retained fruit $/ \mathrm{m}$ and yield compared with the control and other treatment ascendingly during 2012 and 2013 seasons. It should pointed out that foliar sprays with calcium nitrate at $3 \%$ plus $\mathrm{GA}_{3}$ at 10 and $20 \mathrm{ppm}$ in mid May have resulted in an increase over the control by 47.5 and $57.6 \%$ for the first season, and 54.5 and 70.9 for the second season, respectively However, for the No. of fruit drop/m and fruit drop percentage/ $\mathrm{m}$ the control showed the lowest significant values compared to the other treatments in both seasons which reflect a very positive effects in this concern.

Concerning the combinations of Dolce and Manzanillo cvs. with calcium nitrate at $3 \%$ and HoklyGib (10 \& $20 \mathrm{ppm})$ treatments foliar application in mid April, mid May and at pit hardening. Dolce cv. treated with foliar spray of Calcium Nitrate $3 \%$ and HoklyGib (20 ppm) treatment showed the highest significant values compared with the Manzanillo, the other treatments and the control. Manzanillo, other tested combinations showed the intermediate significant value in this concern. Meanwhile, the control treatment showed had the highest values for No. of fruit drop/m and percentage of fruit drop for both cultivars under study.

These results are in agreement with those reported by Tomala (1997) and Zavalloni et al. (2001), who mentioned that the first spray of winter apple cultivars with calcium salts to the at the beginning of June, not later than in the second half of June. According to a several number of studies, foliar application of calcium on apple trees was effective in the second half of vegetation period, when the delivery of $\mathrm{Ca}$ ions to fruits uptake by roots rapidly decreased. Also the effect of $\mathrm{GA}_{3}$ go in line with those reported by Arteca (1996) and Davis (2004). Data of the second season reaffirm these achieved in the first one with more pronounced values.

\section{Fruit characteristics and dimensions}

The effect of Calcium Nitrate (3\%) and (Gibberellic acid) HoklyGib (10 \& $20 \mathrm{ppm}$ ) on fruit length and diameter, fruit shape index, fruit weight (g), seed length and diameter during 2012 and 2013 are shown in Tables 3 and 4. Results showed that Dolce cv. had higher significant values regarding fruit length, fruit shape index and seed length as compared to Manzanillo cultivar gave the highest significant values with Dolce cv. compared to Manzanillo cv. fruit length $(\mathrm{cm})$, fruit shape index and seed length $(\mathrm{cm})$ in both seasons. On the other hand, fruit diameter $(\mathrm{cm}$.), fruit weight $(\mathrm{g}$.) and seed diameter $(\mathrm{cm})$ had the opposite trend with Manzanillo cv. which proved to be superior as compared to Dolce cv. during the two growing seasons of the study.

Egypt. J. Hort. Vol. 41, No.2 (2014) 
EFFECT OF CALCIUM NITRATE AND GIBBERELLIC ACID FOLIAR ... 173

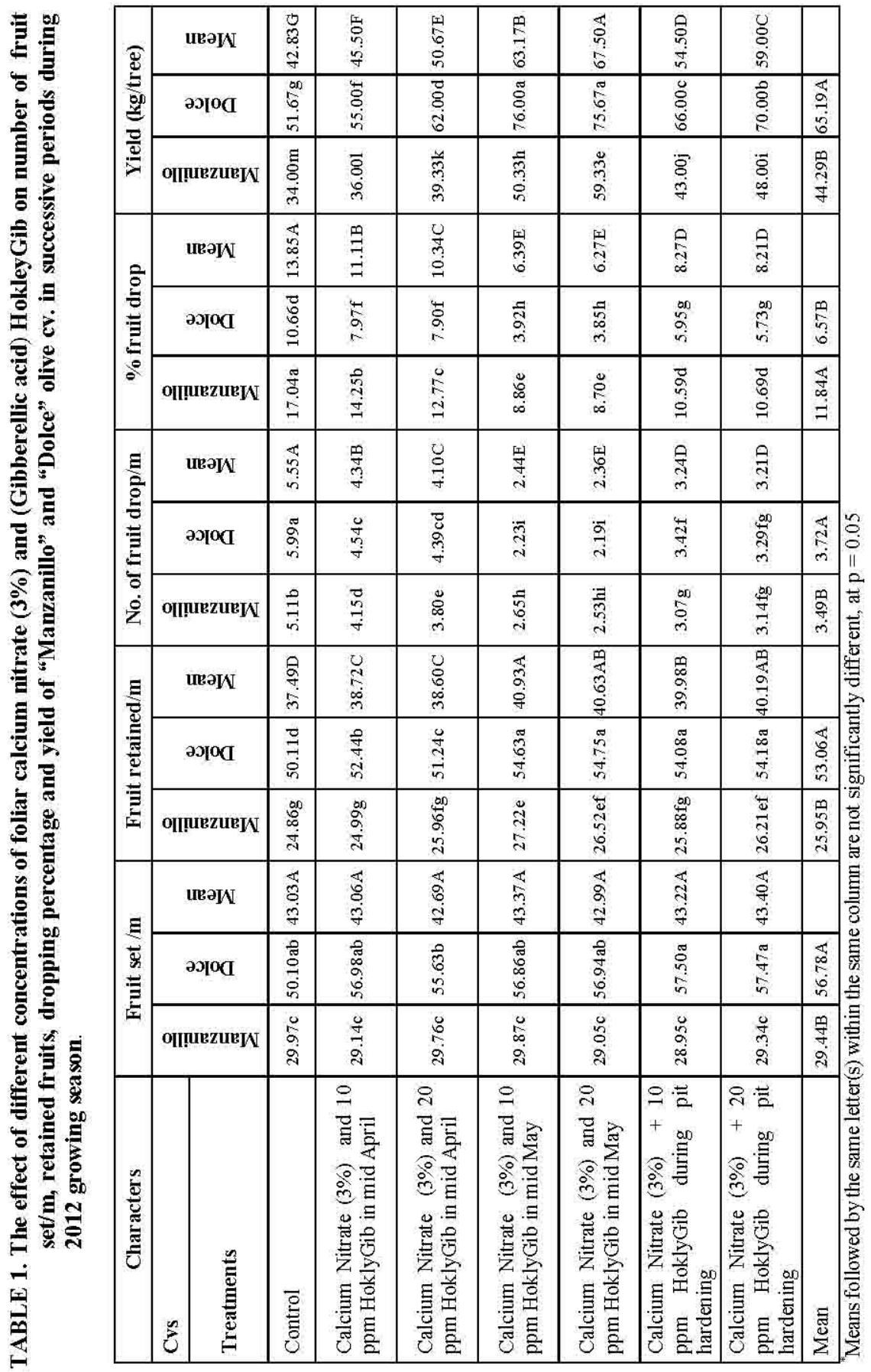

Egypt. J. Hort. Vol. 41, No.2 (2014) 


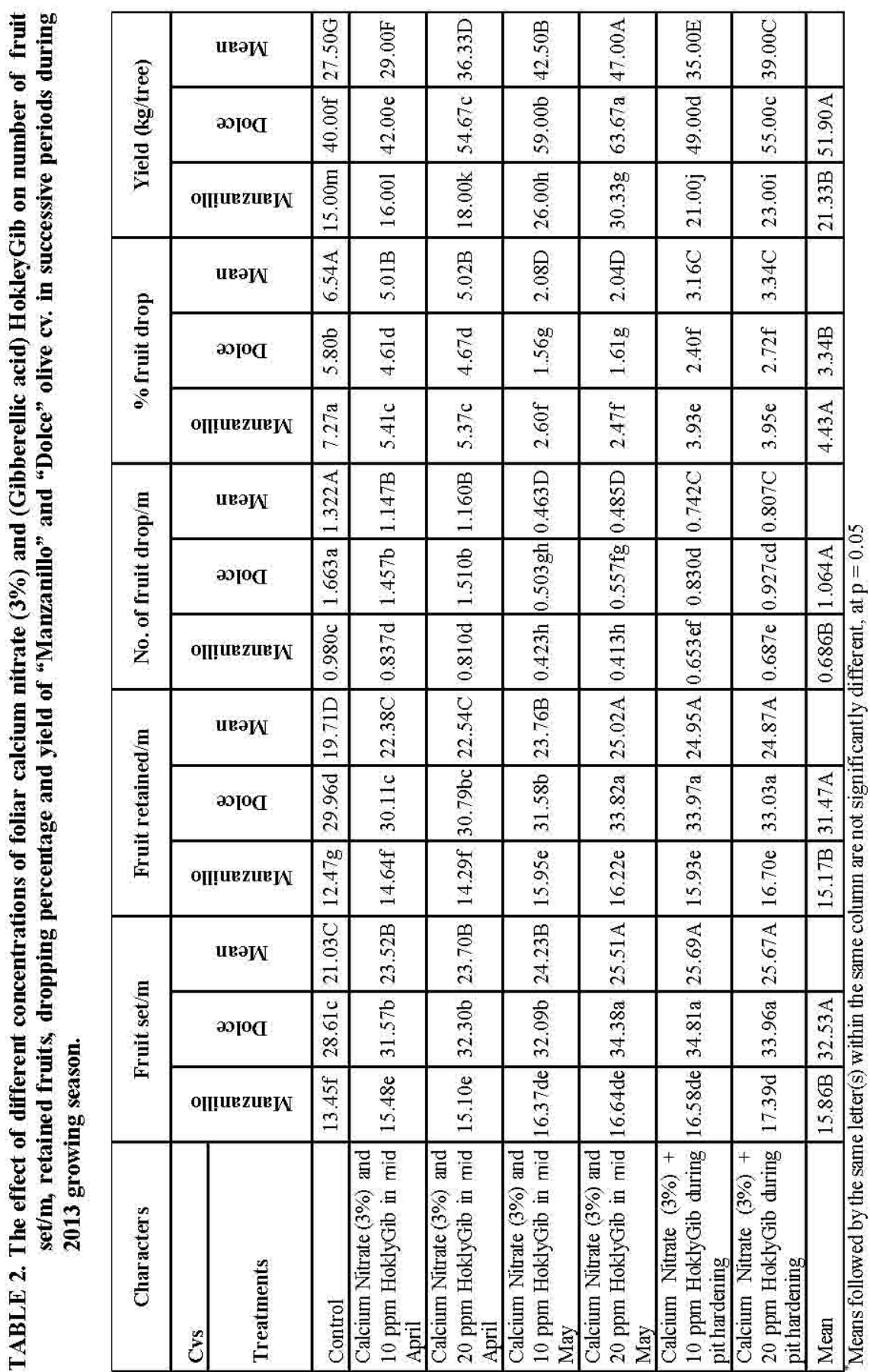


EFFECT OF CALCIUM NITRATE AND GIBBERELLIC ACID FOLIAR ... 175

\begin{tabular}{|c|c|c|c|c|c|c|c|c|c|}
\hline : & ивәШ & 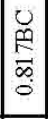 & 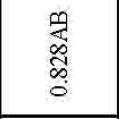 & 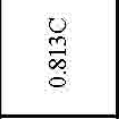 & 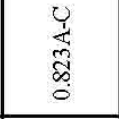 & $\begin{array}{l}\mathbb{J} \\
\stackrel{0}{\infty} \\
\stackrel{0}{0}\end{array}$ & 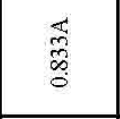 & $\begin{array}{l}\mathbb{J} \\
\stackrel{1}{\infty} \\
\stackrel{0}{0}\end{array}$ & \\
\hline 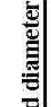 & әоЮО & 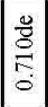 & $\underset{\stackrel{\mathbb{N}}{S}}{\stackrel{0}{0}}$ & $\begin{array}{l}\text { 蓬 } \\
\stackrel{0}{0}\end{array}$ & 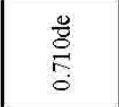 & $\begin{array}{l}\frac{0}{5} \\
\text { ? } \\
\text { 。 }\end{array}$ & $\begin{array}{l}\frac{T}{0} \\
\stackrel{5}{0} \\
\stackrel{0}{0}\end{array}$ & 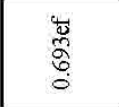 & 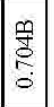 \\
\hline ปัّ & Oा!urzur|র & ڤ్ & $\frac{\ddot{\delta}}{\delta}$ & $\begin{array}{l}\text { ळे } \\
\text { ळे }\end{array}$ & $\stackrel{0}{\delta}$ & $\begin{array}{l}\frac{\AA}{8} \\
\text { ू. } \\
\delta\end{array}$ & 芯 & 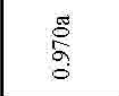 & $\begin{array}{l}\overleftarrow{5} \\
\sigma \\
\sigma \\
0\end{array}$ \\
\hline 园 & ивәуN & $\begin{array}{l}\tilde{m} \\
\check{r} \\
-\end{array}$ & 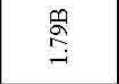 & $\underset{\infty}{\stackrel{\leftrightarrow}{6}}$ & 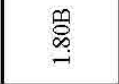 & 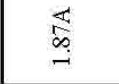 & 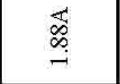 & 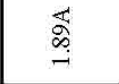 & \\
\hline 혛 & әОЮО⿴囗 & 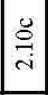 & 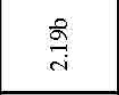 & ત્ડ & $\begin{array}{l}\frac{0}{6} \\
\text { i. }\end{array}$ & $\begin{array}{l}\text { त్ } \\
\text { ते }\end{array}$ & 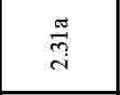 & 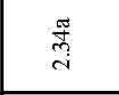 & 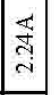 \\
\hline ڤ̊l & oा!uruzurWW & ᄅ్ & 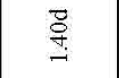 & $\begin{array}{l}\vec{P} \\
\stackrel{\rho}{-}\end{array}$ & 总 & 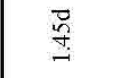 & 总 & $\underset{J}{g}$ & $\stackrel{m}{\stackrel{m}{\sim}}$ \\
\hline 여 & ивәУ & \begin{tabular}{|l}
$\stackrel{0}{0}$ \\
$\stackrel{+}{+}$ \\
\end{tabular} & 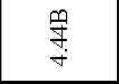 & $\begin{array}{l}\mathbb{3} \\
\vec{n}\end{array}$ & $\underset{+}{\stackrel{9}{+}}$ & $\underset{m}{\stackrel{4}{n}}$ & 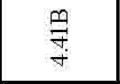 & $\underset{⿱ ㇒}{\mathbb{S}}$ & \\
\hline 형 & әәОО & $\begin{array}{c}\stackrel{a}{\sigma} \\
\stackrel{r}{r}\end{array}$ & 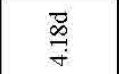 & ‡̊ & $\underset{\vec{T}}{\stackrel{\vec{f}}{f}}$ & ڤू & $\stackrel{\vec{D}}{=}$ & :ू & 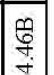 \\
\hline 회 & oा!̣uezurew & 疋 & 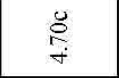 & 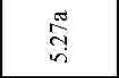 & $\begin{array}{l}\mathscr{\delta} \\
\stackrel{\delta}{+}\end{array}$ & $\begin{array}{l}\text { त̃ } \\
\text { तn }\end{array}$ & $\begin{array}{l}\stackrel{0}{0} \\
\stackrel{+}{*}\end{array}$ & 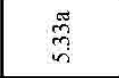 & 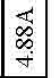 \\
\hline : & ивәШ & 急 & $\underset{\leftrightarrow}{\stackrel{\leftrightarrow}{\leftrightarrow}}$ & کั & 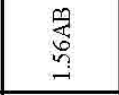 & ڤ્ર & 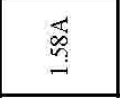 & ڤ్ & \\
\hline 言 & әәЮФ & $\stackrel{2}{\stackrel{2}{\Xi}}$ & $\stackrel{\text { ळ }}{\stackrel{\infty}{-}}$ & $\stackrel{\square}{5}$ & $\stackrel{\mathbb{J}}{\stackrel{\mathbb{S}}{-}}$ & 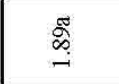 & $\stackrel{\mathbb{S}}{\stackrel{\infty}{\infty}}$ & §̊̆ & 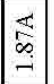 \\
\hline 횜 & oा!!uezurW & 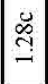 & $\stackrel{\check{~}}{\leftrightarrows}$ & 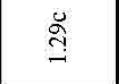 & 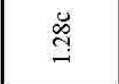 & 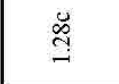 & $\underset{ٌ}{\mathscr{O}}$ & ঙั. & ঙ্ণ \\
\hline 웡 & ивәуN & \begin{tabular}{|l}
0 \\
. \\
0 \\
- \\
\end{tabular} & $\stackrel{\text { 突 }}{2}$ & $\begin{array}{l}0 \\
\text { İ } \\
-1\end{array}$ & $\underset{ت}{\stackrel{f}{F}}$ & 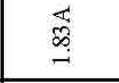 & 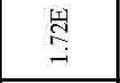 & 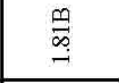 & \\
\hline 产 & әюО人 & $\overrightarrow{\vec{n}}$ & 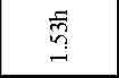 & $\stackrel{4}{6}$ & 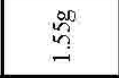 & $\stackrel{\text { ه̆ }}{.}$ & $\begin{array}{l}\infty \\
\\
-\end{array}$ & $\stackrel{8}{\circ}$ & 悉 \\
\hline 司 & OI!!UzZuвW & $\underset{\mathscr{D}}{\vec{D}}$ & $\stackrel{0}{\infty}$ & $\stackrel{7}{9}$ & $\stackrel{\text { ล̊ }}{-}$ & $\stackrel{\pi}{2}$ & $\stackrel{\ddot{\infty}}{\sim}$ & $\stackrel{\Re}{\Omega}$ & ه্ \\
\hline 연 & ивәW & 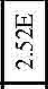 & $\begin{array}{l}\text { त్ } \\
\text { i }\end{array}$ & 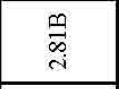 & $\begin{array}{l}8 \\
8 \\
0 \\
ن \\
\end{array}$ & 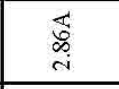 & $\begin{array}{l}\text { U. } \\
\text { i. }\end{array}$ & $\begin{array}{l}\text { 急 } \\
\infty \\
\infty \\
\text { i }\end{array}$ & \\
\hline 형 & әәОО & $\begin{array}{l}\overrightarrow{0} \\
\hat{0} \\
\text { i }\end{array}$ & $\begin{array}{l}\stackrel{8}{\infty} \\
\infty \\
\text { in }\end{array}$ & $\underset{\overbrace{}}{\stackrel{\overbrace{}}{m}}$ & $\begin{array}{l}\stackrel{\mathscr{L}}{\infty} \\
\text { i }\end{array}$ & $\underset{\overbrace{}}{\stackrel{\pi}{m}}$ & ลิ & 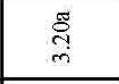 & 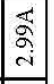 \\
\hline 氞 & оा!!rzurWW & के & $\stackrel{\infty}{\vec{n}}$ & 苦 & 薃 & तั & 楳 & 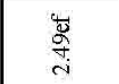 & $\underset{\text { f }}{\stackrel{q}{j}}$ \\
\hline 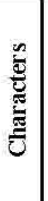 & 总 & 葡 & 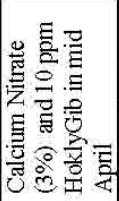 & 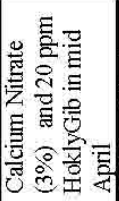 & 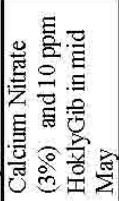 & 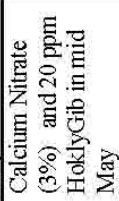 & 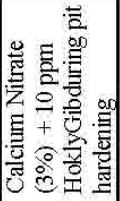 & 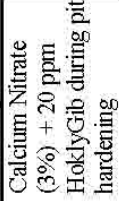 & हूँ \\
\hline
\end{tabular}

Egypt. J. Hort. Vol. 41, No.2 (2014) 


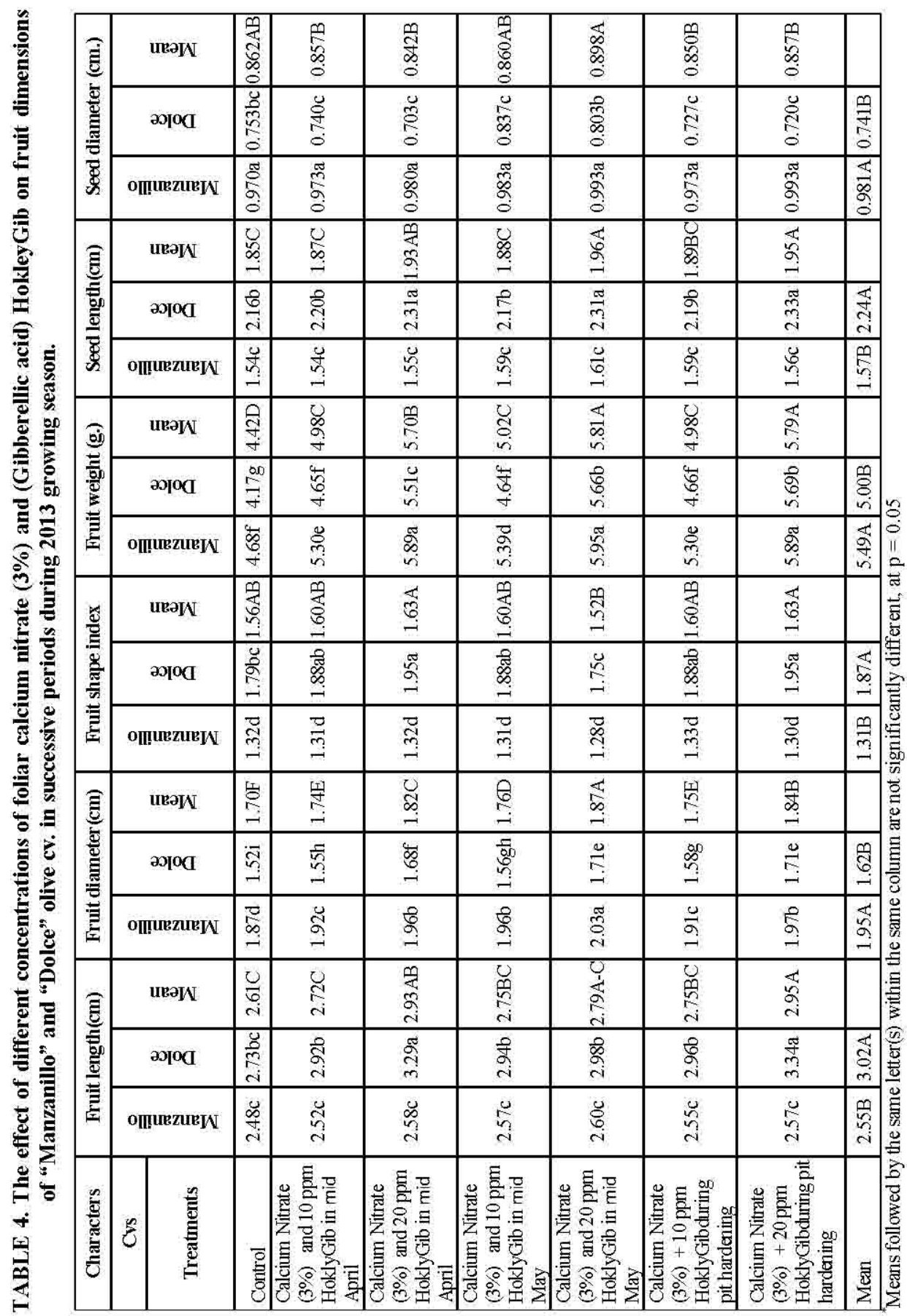


Concerning the effect of the treatments, although there were no significant difference of fruit shape index and seed length compared the control treatment of Dolce and Manzanillo in both seasons, yet, fruit length fruit, diameter, fruit weight and seed diameter were affected significantly with foliar application of calcium nitrate at $(3 \%)$ and HoklyGib $(10 \& 20 \mathrm{ppm})$ in mid May and pit pit hardening treatments in both seasons of the study.

However, data in hand declared distinguished effects regarding fruit weight, seed length and seed weight when calcium nitrate at $3 \%$ was supplemented with $\mathrm{GA}_{3}$ at 10 and $20 \mathrm{ppm}$ in mid April at mid May.

As for the combinations of the effect of the treatments and the two cultivars on fruit length $(\mathrm{cm})$, fruit diameter $(\mathrm{cm})$, fruit shape index, fruit weight $(\mathrm{g})$, and seed diameter $(\mathrm{cm}$.$) the foliar spray of calcium nitrate (3 \%)$ and $20 \mathrm{ppm}$ HoklyGib in mid May with Dolce cv., in the course of pit hardening performed the highest significant value compared with other treatments during both 2012 and 2013 seasons. With Manzanillo cv. it gave the superior values with regard fruit and seed properties without and significant differences in both cultivars. An analogous trend was also obtained in the second season of the study. These results are in harmony with those reported by Neilsen and Neilsen (2002).

\section{Seed weight (g.) and chemical component}

Data in Tables 5 and 6 concerning the inspects of different implemented treatments, obviously pronounced and significant increases in seed weight and flesh weight were noted when calcium nitrate at $3 \%$ was applied with GA3 at 10, $20 \mathrm{ppm}$ in mid May and pit hardening and in mid April, respectively. In the mention no significant effects were noted when dealing with moisture $\%$, oil \% as dry and fresh.

As for the interaction their were significant increases in values of seed and flesh weight of Dolce cv., over the control treatment, whereas no active effects were noticed in values of seed weight and oil \% as dry and fresh weight, regarding Manzanillo cv. data of the second season indicate the same trend as those previously described in the first season.

The proportion of calcium pectate in cell walls is very important for the ripening of fruit and the increase of fruit calcium content leads to the increase in fruit firmness and delays fruit ripening or prevents calcium-related disorders (Ferguson \& Drobak, 1988 and Zocchi \& Mignani, 1995). High growth rates of low-transpiring organs increase the risk of calcium tissue content falling below the critical level required for cell wall stabilization and membrane integrity. Foliar calcium spraying can be an more or less effective way of increasing its concentration in fruits (Casero et al., 2002, Neilsen \& Neilsen, 2002 and Tomala \& Soska, 2004). 


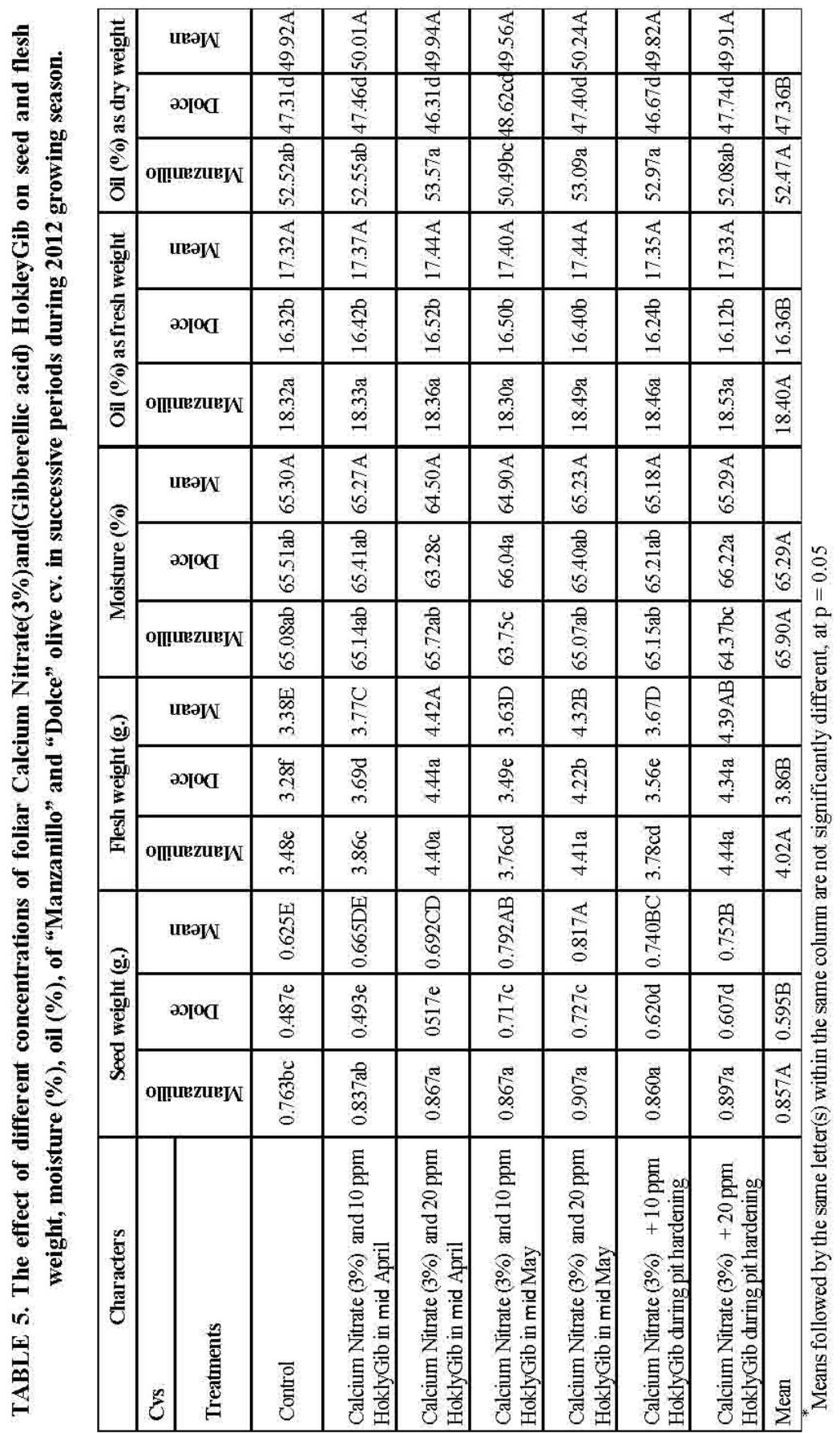




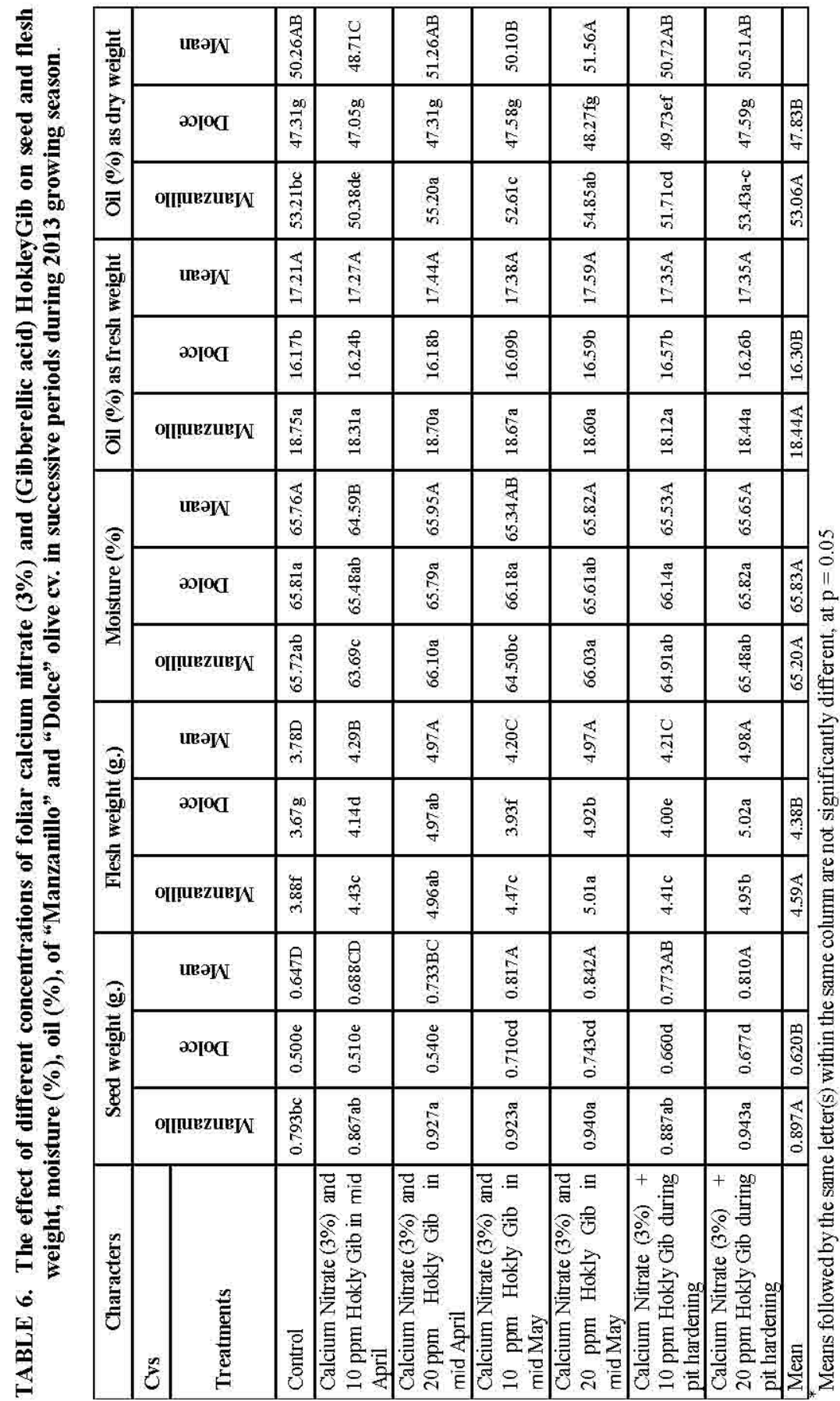




\section{Conclusions}

Conclusively, it could be mentioned on the basis of the obtained results that foliar sprays with calcium nitrate at $3 \%$ plus $\mathrm{GA}_{3}$ at 10 and $20 \mathrm{ppm}$ in (midMay), (treatments during pit hardening) and (mid-April) respectively for both "Manzanillo" and "Dolce" cvs. could be recommended to improve yield and fruit quality especially oil content.

\section{References}

A.O.A.C. (1975) "Official Methods Analysis", $12^{\text {th }}$ ed., Association of Official Analytical Chemists, Washington, DC.

Arteca, R.N. (1996) Plant Growth Substances: Principles and Applications. Chapman and Hall Press, New York, USA, p.332.

Beltrán, G., del Río, C., Sánchez, S., and Martínez, L. (2004) Seasonal changes in olive fruit characteristics and oil accumulation during ripening process. J. Sci. Food Agric., 84 (13), 1783-1790.

Casero, T., Benavides A., Recasens, I. and Rufat, J. (2002) Preharvest calcium sprays and fruit calcium absorption in 'Golden' apples. Acta Hort., 594, 467-473.

Chang, J.C. and Lin, T.S. (2006) $\mathrm{GA}_{3}$ increases fruit weight in 'Yu Her Pau' litchi. Sci. Hort. 108(4), 442-443.

Davis, P.J. (2004) The plant hormones: their nature, occurrence and functions. In: Plant Hormones. Davis, P.J. (Ed.), Kluwer Academic Publishers, Dordrecht, The Netherlands, pp. 1-15.

Desouky, M.I., Lilaa H., Abd El-Magid, M.M., Kishk, Y.F. and El-Hady, E.S. (2009) Effect of boron and calcium nutrient spray on fruit set, oil content and oil quality of some olive oil cultivars. World J. Agric. Sci., 5 (2),180-185.

Duncan, D.B. (1955) Multiple range and multiple F. Test. Biometrics, 11, 1-42.

El-Khawaga, A., Abou El-Khashab, A.M. and El-Iraqy, A.M. (2007) impact of water withholding before ripening, zinc and glutathion on fruit splitting and productivity of manfaloty pomegranate. Menia University, Faculty Agric., Menia J. Agric. Res. and Development, 27 (3), 481-496

El-Sayed, M.E. and AbouShanab, I.S. (2011) Olive Growing in Egypt. A pamphlet publication, Hort. Res. Inst., Giza, Egypt.

El-Sese A.M.A. (2005) Effect of gibberellic acid $\left(\mathrm{GA}_{3}\right)$ on yield and fruit characteristics of Balady mandarin. Assiut J. Agric. Sci., 36 (1), 23-35.

El-Sharkawy, S.M.M. and Mehaisen, S.M.A. (2005) Effect of gibberellin and potassium foliage sprays on productivity and fruit quality of guava trees. Egypt J. Appl. Sci., 20(3), 151-162. 
EFFECT OF CALCIUM NITRATE AND GIBBERELLIC ACID FOLIAR ... 181

Eman, A.A., Abd El-Moneim, M.M., Abd El-Migeed, O. and Ismail, M.M. (2007) $\mathrm{GA}_{3}$ and Zinc Sprays for Improving Yield and Fruit Quality of Washington Navel Orange Trees Grown under Sandy Soil Conditions. Res. J. Agric. Biol. Sci., 3(5), 498503.

Ferguson, I. and Drobak, R. (1988) Calcium and the regulation of plant growth and senescence. Hort. Sci., 23, 262-266.

Glenn, G.M., Reddy, A.S.N. and Poovaiah, B.W. (1988) Effect of calcium on cell wall structure, protein phosphorylation and protein profile in senescence apples. Plant Cell Physiol., 24, 565-573.

Himelrick, D.G. and Mcduffie, R.F. (1983) The calcium cycle: Uptake and distribution in apple trees. J. Hort. Sci. Biotech., 18, 147-149.

Makwana, V., Shukla, P. and Robin, P. (2010) Comparing potential of GA and 2, 4-D in increasing fruit yield from Jatrophacurcas, J. Biofuels, 1, 157-162.

Marschner, H. (1995) Mineral nutrition of higher plants. Academic Press, London.

Mengel, K., (2002) Alternative or complementary role of foliar supply in mineral nutrition. Acta Hort., 594, 33-47

Neilsen G.H. and Neilsen, D. (2002) Effect of foliar Zn, form and timing of Ca sprays on fruit $\mathrm{Ca}$ concentration in new apple cultivars. Acta Hort., 594, 435-443.

Pharis, R.P. and King, R.W. (1995) Gibberellic and reproductive development in seed plants. Ann. Rev. Plant Physiol., 36, 517-568.

SAS Institute. (1986) "SAS Users Guide Statistics", $6^{\text {th }}$ ed., SAS Institute Inc. Cary. NC USA

Snedecor, G.W. and Cochran, W.G. (1980) "Statistical Methods" $7^{\text {th }}$ ed., Iowa State Univ. Press, Ames, Iowa, U.S.A., 507p.

Stern, R.A. and Gazit, S. (2000) Reducing fruit drop in lychee with PGR sprays. In: Plant Growth Regulators in Agriculture and Horticulture, Basra, A. (Ed.), The Haworth Press Inc., New York, USA, pp. 211-222.

Tomala, K. (1997) Predicting storage ability of Cortland apples. Acta Hort., 448, 67-74.

Tomala, K. and Soska, A. (2004) Effects of calcium and/or phosphorus sprays with different commercial preparations on quality and storability of Šampion apples. Hort. Sci., 34, 12-17.

Tretyn, A. (1994) Wapń w komórkacheukariotycznych. PWN, Warszawa. [In Polish].

Zavalloni, C., Marangoni, B., Tagliavini, M. and Scudellari, D. (2001) Dynamics of uptake of calcium, potassium and magnesium into apple fruit in a high density planting. Acta Hort., 504, 113-121. 
Zhang, C., Tanabe, K. Tani, H., Nakajima, H., Mori, M., Itai, A. and Sakuno, E, (2007) Biologically active gibberellins and abscisic acid in fruit of two late-maturing Japanese pear cultivars with contrasting fruit size. J. Am. Soc. Hort. Sci., 132, 452-458

Zocchi, G. and Mignani, I. (1995) Calcium physiology and metabolism in fruit trees. Acta Hort., 383, 15-20

(Received 17/6/2014; accepted $3 / 9 / 2014)$

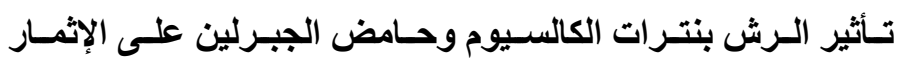 وصفات جودة الثمار فى صنفي الزيتون منزانيللو ودولسي الني

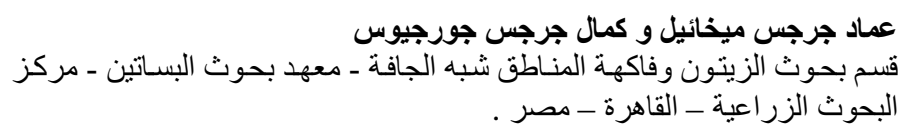

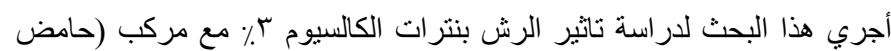

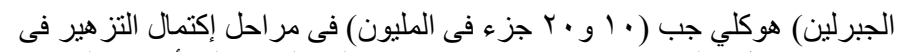

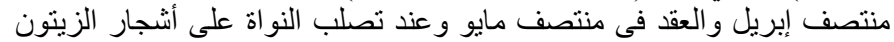

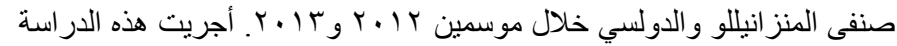

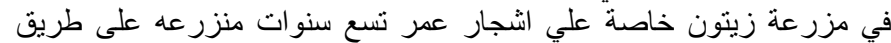

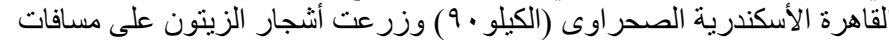
ع × 7 م وتروى بنظام الري بالتنقيط.

وحيث أن القيمة الاقتصادية للزينون تتحدد بكمية المحصول وجودة الثمار

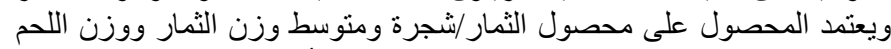

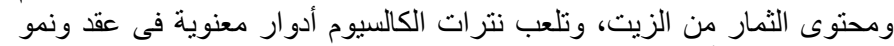
و اكتمال الثمار و أظهرت المعن المعاملات الاتى :

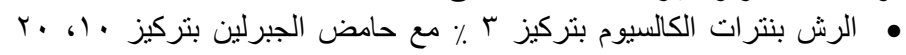

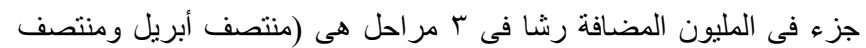

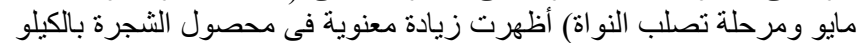

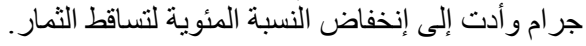

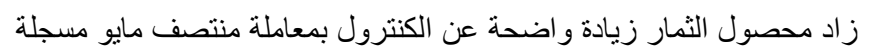

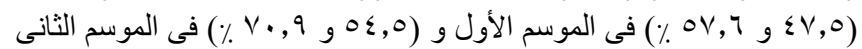

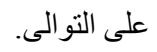

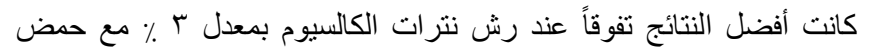

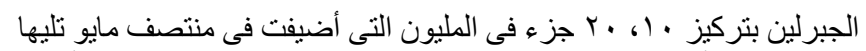

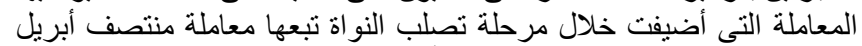

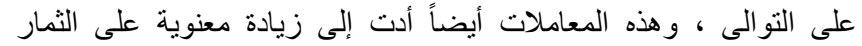

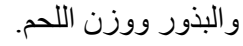

